\title{
Hereditary angioedema type 2
}

INSERM

\section{Source}

INSERM. (1999). Orphanet: an online rare disease and orphan drug data base. Hereditary angioedema type 2. ORPHA:100051

Hereditary angioedema type 2 ( $\mathrm{HAE} 2$ ) is a form of hereditary ang ioedema (see this term) characterized by acute edema in subcutaneous tissues, viscera and/or the upper airway. 